\title{
SADNJA SADNICA POLJSKOG JASENA (Fraxinus angustifolia Vahl) U UVJETIMA SANACIJE SUMSKIH SASTOJINA USLIJED SUŠENJA
}

\section{PLANTING SEEDLINGS OF NARROW-LEAVED ASH (Fraxinus angustifolia VAHL) TO RECOVER DIEBACK-AFFECTED FOREST STANDS}

\author{
Damir DRVODELIĆ ${ }^{1}$, Milan ORŠANIĆ2
}

\begin{abstract}
SAŽETAK
U ovom preglednom članku nabrojene su i objašnjene prednosti sadnje krajem ljeta i početkom jeseni kao i proljetne sadnje prije početka vegetacije. Opisano je i s originalnim ilustracijama prikazano nepravilno i pravilno kopanje sadne jame kao i nepravilna i pravilna sadnja sadnica poljskog jasena golog korijena. Objašnjen je utjecaj zbijenosti tla na klijavost sjemena, razvoj klijanca, morfološke značajke nadzemnog i podzemnog dijela sadnica i korijenskog sustava. Raspravlja se o manama kontejnerske proizvodnje šumskih sadnica u čistom organskom mediju poput crnog treseta i nedostacima kod sadnje tako proizvedenih sadnica na terenu. Opisana je i s originalnim ilustracijama prikazana pravilno i nepravilno posađena kontejnerska sadnica poljskog jasena. Prikazana je suvremena tehnologija rasadničke proizvodnje sadnica poljskog jasena u kontejnerima te prednosti pošumljavanja sadnicama obloženog korijena. Kontejnerska proizvodnja je polu automatizirana i sadnja na terenu bi se isključivo trebala obavljati uz pomoć sadilja čije su značajke i prednosti prikazane u članku. Opisana su inovativna rješenja kod konstrukcije sadilja s obzirom na oblik rupe koju rade. Važno da rupe koju rade sadilje ne budu okruglog ili kvadratnog/pravokutnog oblika jer u tom slučaju dolazi do razdvajanja ili pucanja rupe za sadnju od okolnoga tla. Kod sadilja koje rade rupu romboidnog oblika ili iskopane sadne jame, ne dolazi do pucanja po rubu rupe već rupa puca po cijelom profilu što je povoljnije za korijenski sustav biljke. Originalnim ilustracijama su prikazani primjeri loših i dobrog geometrijskog oblika sadne jame. Na primjeru iz rasadnika „Brestje“ u Sesvetama (Hrvatske šume d.o.o.) prikazana je tehnologija rasadničke proizvodnje kontejnerskih sadnica poljskog jasena. Uspoređeni su podaci iz deklaracije supstrata korištenog kod kontejnerske proizvodnje sadnica s rezultatima vlastitih kemijskih analiza istoga u trenutku sadnje sadnica na terenu nakon jedne vegetacije uzgoja. Opisuje se ekstrakcija elemenata iz uzoraka supstrata kao i priprema uzoraka za određivanje sadržaja elemenata u tragovima tehnikom ICP-AES. Prikazani su vrijednosti glavnih parametara supstrata dobivenih tehnikom ICP-AES kao i udjel makro i mikro hranjiva u supstratu. U članku su prikazane glavne morfološke značajke kontejnerskih sadnica poljskog jasena pošumljene na području šumarije Lipovljani u jesen 2017. godine. Posebno je prikazan izgled opranog korijenskog sustava prosječne kontejnerske sadnice i njegova morfološka analiza uz pomoć skenera i softvera WinRHIZO ProLA2400 (2005). Opisani su uzroci velikog mortaliteta sadnica poljskog jasena kod pošumljavanja na području Republike Hrvatske s konkretnim mjerama za poboljšanje sadašnjeg stanja s obzirom na dobre šumarske prakse koje se provode u zemljama srednje Europe i Skandinavije.
\end{abstract}

KLJUČNE RIJEČI: nepravilna sadnja, pravilna sadnja, kontejnerske sadnice, tresetni supstrati, morfologija korijena

\footnotetext{
1 Doc. dr. sc. Damir Drvodelić, Šumarski fakultet Sveučilišta u Zagrebu, Svetošimunska 25, 10000 Zagreb, email: ddrvodelic@inet.hr

${ }_{2}^{2}$ Prof. dr. sc. Milan Oršanić, Šumarski fakultet Sveučilišta u Zagrebu, Svetošimunska 25, 10000 Zagreb
} 


\section{UVOD}

\section{INTRODUCTION}

Na uspjeh preživljavanja šumskih sadnica nakon sadnje utječe njihova genetska, morfološka i fiziološka kvaliteta o kojoj pišu mnogi autori (Adams i Patterson, 2004; Drvodelić i Oršanić 2019; Mexal i Landis 1990; Oršanić i dr. 2007; Oršanić i dr. 2008a; Oršanić i dr. 2008b; Drvodelić i dr. 2012; Drvodelić i dr. 2013; Drvodelić i dr. 2015; Drvodelić i dr. 2016a; Drvodelić i dr. 2016b; Drvodelić i dr. 2016c; Crnković i dr. 2017; Paterson i dr. 2001; Smith 1975; Cleary i Zaerr, 1980; Ritchie 1984; Harrington i dr. 1994; Thompson 1985; Omi i dr. 1986; Blake i dr. 1989; South i dr. 1988; Rose i Ketchum 2003; Roller 1977; Kozlowski i dr. 1973; Rose i dr. 1997; Jacobs i dr. 2005; Jelić i dr. 2014; Tsakaldimi i dr. 2005; Faulconer 1988; Burr 1990; Burr i dr. 1990; Lopushinsky 1990; Simpson 1990; Glerum 1984; Tanaka i dr. 1997; Ritchie 1985; Simpson i Ritchie 1997; Bobinec Mikek, D. 2009; Oršanić i dr. 2010; Lavender 1985; Owens i Molder 1973; Landis 1985; van den Driessche 1980; Haase i dr. 2006; Drvodelić 2017), ali i kvalitetna sadnja na terenu. Ponekad je ispravna sadnja ključna za preživljenje i dobar inicijalni rast sadnica nego njezine određene kvalitativne karakteristike.

Sadnja sadnica gologa korijena obavlja se za vrijeme mirovanja vegetacije kada su pupovi i korijenski sustav dormantni. Vrijeme sadnje ovisi o klimatskim uvjetima na mjestu sadnje odnosno rasporedu padalina. U slučaju sadnje sadnica poljskog jasena ona se obavlja u trenutku kada nam dopuste vremenski uvjeti i uvjeti tla. Naime, tlo ne smije biti pod poplavom niti previše vlažno. U nekim situacijama sadnja se može odgoditi pred kraj proljeća a sadnice bi u tom slučaju trebalo držati na polju u rasadniku i po potrebi izvaditi i čuvati u hladnjačama na ispravan način. Prednosti kontejnerskih sadnica je produženo vrijeme sadnje i manji šok zbog presadnje. Prema Harris i dr. (2004), prednosti sadnje krajem ljeta i početkom jeseni očituju se u tome što toplo tlo potiče rast korijena a kraći i hladniji dani smanjuju transpiraciju biljaka. Proljetna sadnja prije početka vegetacije najpovoljnija je zbog: toplijeg vremena, rasta korijena prije rasta izbojaka i dovoljne količine vlage u tlu. Ako se radi proljetna presadnja, često nakon povlačenja poplavnih voda u kontinentalnom dijelu, treba je obaviti što je moguće ranije, odnosno prije nego što sadnica počinje s razvojem novoga korijena (Root growth capacity). Kod gotovo svih listopadnih vrsta umjerenoga pojasa, korijen raste još neko vrijeme nakon otpadanja lišća, a isto tako počinje rasti u tlu prije bubrenja pupova i početka praćenja proljetne fenofaze biljaka. Bez obzira na vrijeme sadnje, sadnice nije preporučljivo saditi po ekstremno hladnim, vrućim, suhim i vjetrovitim uvjetima.

Sadnju treba obaviti nakon što se povuče poplavna voda i u uvjetima iste vlažnosti tla. Za to postoje jeftini vlagomjeri tipa ThetaProbes tipa ML2x. Oni uz pomoć senzora mjere trenutnu vlagu u tlu. Zbog uniformnosti mjerenja, važno je mjeriti vlagu na površini tla na istoj dubini i na dnu sadne jame koja ovisi o starosti sadnica i njihovoj veličini (oko 40 $\mathrm{cm})$. Sadnju treba obavljati što manje ljudi zbog uniformnosti rada i subjektivnosti. Sadnice se inače sade na istu dubinu na kojoj su bile u rasadniku, ali kod poljskog jasena one se trebaju posaditi barem $2 \mathrm{~cm}$ niže, tako da je korijenski vrat sadnica u tlu. To je važno kako ne bi došlo do razdvajanja i stvaranja pukotina na rubovima sadne jame. Prilikom kopanja sadne jame, gornje, humusom bogatije tlo treba staviti s jedne a donje tlo sa druge strane sadne jame. Donji dio sadne jame i bočne stranice ne smiju biti zaglađene već se moraju usitniti tj. površinski obraditi motikom ili nekim prikladnim alatom kako bi se korijenu omogućio što lakši rast u dubinu i širinu i kako bi se uspostavio dobar kontakt tla s kojim se zatrpava sadna jama s matičnim tlom. U suprotnom, tijekom ljeta, ako se to ne učini, nastaju raspukline zbog utezanja gline i do korijena dolazi zrak koji ga isušuje. To se naziva desikacija korijena. Dno jame potrebno je probiti u dubinu barem $15-20 \mathrm{~cm}$ zbog lakšeg vertikalnog procjeđivanja vode koja se ne smije dugo zadržavati u zoni korijena biljke. To se može napraviti štihačom ili šipkom za rahljenje tla kakva se koristi u arborikulturi kod sadnje urbanih stabala. Probijanje dna sadne jame važno je i zbog rasta korijena u dubinu, posebno kod hrastova i oraha koji imaju izrazitu žilu srčanicu ili glavni korijen. Gornjim tlom koje je izvađeno treba se prvo staviti oko korijena ali se prethodno mora što bolje usitniti. Zatim se sadna jama zatrpava donjim tlom, također finije strukture. Ukoliko se izvađeno donje tlo iz sadne jame također ne usitni, dolazi preko ljeta do razdvajanja korjenovog busena s tresetom od matičnog tla. Korijen mora biti pravilno postavljen-pozitivno geotropno (prema dolje), bez pretjeranog gužvanja i usmjeravanja korijenskog sustava. Naročito je važno kod zatrpavanja sadne jame ne gaziti tlo nogama već se sve treba odraditi pritiskom ruku. To je naročito važno u uvjetima veće vlažnosti tla.

Teška hidromorfna tla imaju mali kapacitet za zrak. Sabijanjem sadnice nogama, kapacitet tla za zrak se umanjuje što utječe na to da se kisik istiskuje iz mikro i makro pora tla i dolazi čak do gušenja korijena zbog nedostatka kisikahipoksija. Naročito je važna korijenu poljskog jasena dovoljna količina kisika za rast, voda nije problem niti ostali čimbenici.

Na slici 1. prikazano je nepravilno kopanje sadne jame i nepravilna sadnja sadnica poljskog jasena gologa korijena.

Sabijenost tla mjeri se penetrometrom do maksimalno 0,8 $\mathrm{m}$ dubine. Upravo ovakvim mjerenjima je dokazano kako je kritična vrijednost za rast korijenskog sustava oko $2 \mathrm{MPa}$. Izradom tzv. „krtičnjaka“ iznad sadne jame gdje je tlo prekopano utječe na bolju vodo propusnost. U slučaju kada se 

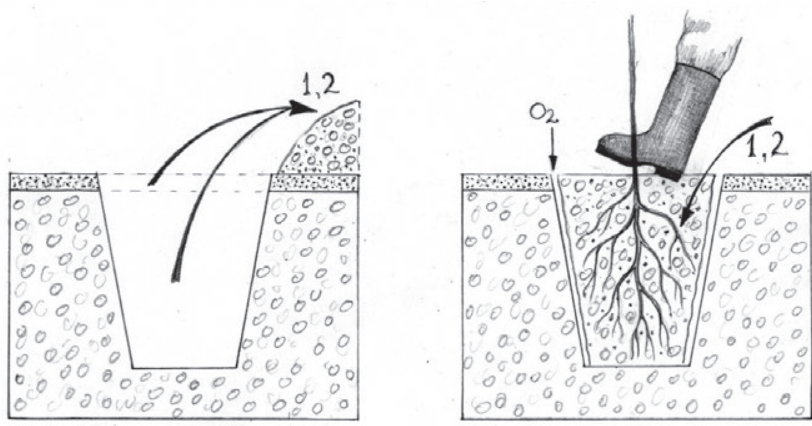

Slika 1. Nepravilno kopanje sadne jame (lijevo) i nepravilna sadnja (desno) sadnica poljskog jasena gologa korijena. (izradio: doc. dr. sc. Damir Drvodelić; ilustracija: akademski slikar Ivica Gabrić)

Figure 1. Incorrect digging of a planting pit (left) and incorrect planting (right) of bare root seedlings of narrow-leaved ash (Fraxinus angustifolia Vahl). (Made by Damir Drvodelić, Ph.D., illustrated by: Ivica Gabrić, academy-trained painter).
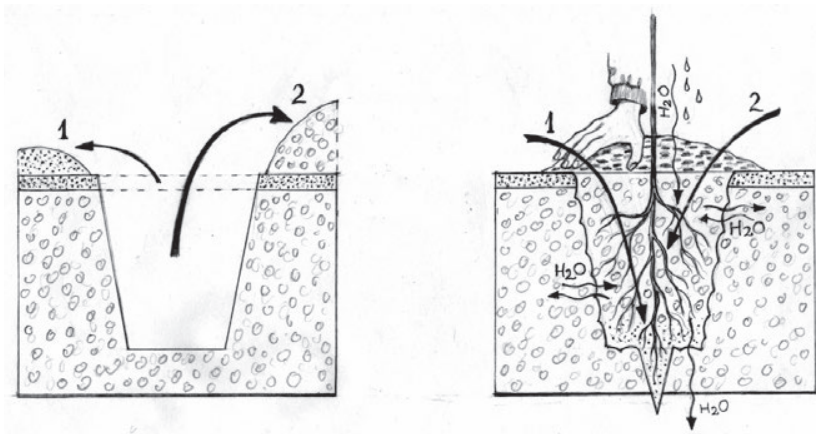

Slika 2. Pravilno kopanje sadne jame (lijevo) i pravilna sadnja sadnica poljskog jasena gologa korijena. (izradio: doc. dr. sc. Damir Drvodelić; ilustracija: akademski slikar Ivica Gabrić).

Figure 2. Proper digging of a planting pit (left) and proper planting of bare root seedlings of narrow-leaved ash (Fraxinus angustifolia Vahl). (Made by: Damir Drvodelić, Ph.D., illustrated by: Ivica Gabrić, academy-trained painter).

sadna jama zatrpava krupnim komadima tla i pri tome se sadnica sabija nogama, tzv. „krtičnjaci“ nemaju značajniju funkciju. Sadnice se kod sadnje obavezno trebaju sabijati usitnjenim matičnim tlom laganim pritiskom rukama a ne nogama.

Na slici 2. prikazano je pravilno kopanje sadne jame i pravilna sadnja sadnica poljskog jasena gologa korijena.

Ako voda ne otječe, u tlu nema dovoljno kisika za rast i razvoj korijenskog sustava. Sadržaj hranjiva u tlu, tekstura i kompaktnost tla smatramo da su jedni od važnijih čimbenika koji utječu na korijenski sustav biljke (Cambi i dr. 2018). Zbijenost tla utječe negativno na morfologiju i anatomiju korijenskog sustava sadnica poljskog jasena (smanjuje se udio fiziološki aktivnog korijenja, specifična duljina korijena i udio ksilema korijena). Korijen utječe na fiziološke (transpiracija, fotosinteza,...) čimbenike i rast biljke. Slabo razvijen korijenski sustav za posljedicu ima i slab rast i razvoj nadzemnog dijela. Kod umjetne obnove sadnjom sadnica na glejnim tlima važna je dobra dreniranost tla zbog čega površinu prije sadnje treba mehanički pripremiti prikladnim oruđima. Sadnice kao i prirodni pomladak poljskog jasena ne trpe korovsku konkurenciju (amorfa i sl.). uslijed čega dolazi do odumiranja biljaka.

Sadnja kontejnerskih sadnica obavlja se u ručno ili strojno iskopane rupe s time da se sadnica posadi za $2 \mathrm{~cm}$ niže u sadnu jamu kako bi se tresetni busen mogao prekriti matičnim glinovitim razrahljenim tlom. Ukoliko se sadnja obavlja krajem ljeta i početkom jeseni, iznad površine oko sadnice se nekim alatom ili rukama napravi mali tzv. „krtičnjak" u visini oko $5 \mathrm{~cm}$ kako bi se spriječilo razdvajanje tresetnih supstrata od matičnog hidromorfnog tla. Nakon jedne vegetacije ti „krtičnjaci“ se slegnu u razini okolnoga tla a sadnica je razvila već dovoljno snažan korijenski sustav u širinu i dubinu izvan zone tresetnog supstrata. Kod proljetne sadnje, također su poželjni „krtičnjaci“. Na slici 3. prikazana je pravilno i nepravilno posađena kontejnerska sadnica poljskog jasena.

U sušnom razdoblju, glina se uteže, a treset sakuplja pa između nastaju pukotine koje isušuju korijen sadnice koja neizostavno ugiba. Predlaže se uzgoj kontejnerskih sadnica u rasadniku u takozvanim projektiranim (inženjerskim) kontejnerima s obzirom na biološke osobine sadnica poljskoga jasena (posebno korijenskog sustava) i unaprijed definiranu duljinu uzgoja u mjesecima. Osim kontejnera potrebno je definirati i ostale čimbenike u rasadničkoj proizvodnji kontejnerskih sadnica (vrijeme uzgoja, nosače, sustav navodnjavanja i fertirigacije, vrstu supstrata i gnojiva i dr.). Zbog desikacije korijena, kontejnerske sadnice trebale bi biti na kompatibilnim nosačima. Iznad nosača projektira se sustav navodnjavanja odozgora (samopokretna kišna krila) za vlagu u supstratu i zamagljivanje (zaštita od biljnih bolesti i štetnika, folijarna prihrana). Treset kao supstrat ima dobra fizikalna, ali loša kemijska svojstva. On se ne smatra hranjivom već potencijalnim hranjivom, nakon hu-
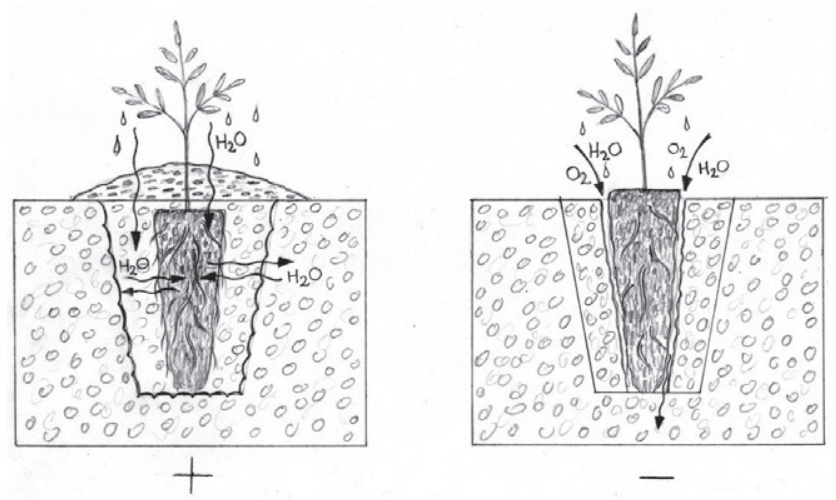

Slika 3. Pravilno (+) i nepravilno ( - ) posađena kontejnerska sadnica poljskog jasena. (izradio: doc. dr. sc. Damir Drvodelić; ilustracija: akademski slikar Ivica Gabrić).

Figure 3. Correctly $(+)$ and incorrectly $(-)$ planted container seedling of narrow-leaved ash (Fraxinus angustifolia Vahl). (Made by: Damir Drvodelić, Ph.D., illustrated by: Ivica Gabrić, academy-trained painter). 
mifikacije i mineralizacije. Za svaku biljku najvažniji je dobro razvijen i zdrav korijenski sustav, a za rast korijena od primarne je važnosti dovoljna količina kisika, nakon čega slijede ciljana biljna hranjiva i voda. Supstrati bi trebali biti porozni (oko 70\%), rahli, dobrog kapaciteta za zrak (20-25 $\%)$ i s dobrom adsorpcijom vode. U arborikulturi se često koristi kod sadnje supstrat iz recikliranog građevinskog materijala (drobljena cigla) dimenzija čestica od 0,16 - 0,20 $\mathrm{cm}$. Takav supstrat čuva vlagu tijekom razdoblja suše i dovodi je prema korijenu biljke (Harris i dr. 2004). Ukoliko se radi o supstratima na bazi čistog crnog treseta (bez dodatka hranjivih tvari) oni se mogu oplemeniti s minimalnom ciljanom dozom gnojiva s kontroliranim otpuštanjem hranjivih tvari (tipa Osmocote) koja će se u potpunosti razgraditi do jeseni prije sadnje. Gnojiva tipa Osmocote su dobra, ali nisu termostabilna što znači da ukoliko se temperatura u kontejneru jako poveća ona brže otpuštaju hranjive tvari nego što piše na deklaraciji. Deklarirana dugovječnost otpuštanja Osmocote gnojiva vrijedi ukoliko je prosječna dnevna temperatura $21^{\circ} \mathrm{C}$ (https://everris.com). $\mathrm{U}$ tom smislu, za kontejnersku proizvodnju sadnica bolja su termostabilna gnojiva tipa Silvamix koja se proizvode u

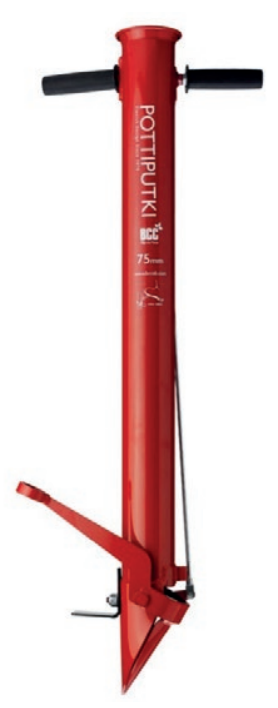

Slika 4. Sadilja proizvođača BCC (Pottiputki-Planting tube 75, unutarnja dimenzija $73 \mathrm{~mm}$, duljina $935 \mathrm{~mm}$ i težina $3550 \mathrm{~g}$ ).

Figure 4. Planting tube BCC (Pottiputki-planting tube 75, internal dimension $73 \mathrm{~mm}$, length $935 \mathrm{~mm}$ and weight $3550 \mathrm{~g}$ ).
Češkoj (https://www.silvamix.com/). Supstrat bi u jesen trebao biti bez hranjivih tvari iz razloga što u tom slučaju korijen sam traži izvor hranjiva i prorasta van busena od supstrata što je povoljnije za sadnicu. Ukoliko u supstratu ima puno hranjiva, biljka „razmišlja“ "na način da korijenski sustav ne raste van supstrata (u okolno tlo) koje je puno siromašnije biljnim hranjivima. Veći dio hranjiva sadnice trebaju usvajati putem lista što znači folijarnom ciljanom prihranom. Ona se obavlja u čestim intervalima. Osnovna prednost uzgoja sadnica u kontejnerima je produženo vrijeme sadnje, osim kada tlo nije smrznuto ili pod snijegom a biljke doživljavaju manji stres zbog presadnje. Ipak se preporuča, u slučaju poljskog jasena, sadnju kontejnerskih sadnica obaviti od druge polovice kolovoza na dalje.

\section{Oruđa za sadnju sadnica poljskog jasena}

Sadnja kontejnerskih sadnica treba se obaviti sadiljama za tu vrstu kontejnera (ako postoje). Sadilje su ekonomičniji i brži način sadnje te ergonomski prihvatljiviji. Dobar primjer kvalitetnih kontejnera su BCC kontejneri (http://www. bccab.com/) uz koje se mogu kupiti odgovarajuće sadilje (Pottiputki) (slika 4.).

\section{Tehnička svojstva sadilja}

Svaku sadilju karakteriziraju tri čimbenika: unutarnja dimenzija u $\mathrm{mm}$, duljina u $\mathrm{mm}$ i težina u g. Za projektirane (inženjerske) kontejnere, mogu se po narudžbi izraditi i prikladne sadilje za sadnice. Kod sadilja je važno da rupe za sadnju ne budu okruglog ili kvadratnog/pravokutnog oblika jer u tom slučaju dolazi do razdvajanja ili pucanja rupe za sadnju od okolnoga tla. Kod sadilja koji rade rupu romboidnog oblika ili iskopane sadne jame, ne dolazi do pucanja po rubu rupe već rupa puca po cijelom profilu što je povoljnije za korijenski sustav biljke. Na slici 5. prikazana su dva primjera lošeg i jedan primjer dobrog geometrijskog oblika sadne jame koja se radi sadiljima.

Cilj ovoga rada je ukazati na ispravnu sadnju sadnica poljskog jasena golog i obloženog korijenskog sustava kao i na problematiku vezanu uz rasadničku proizvodnju kontejnerskih sadnica poljskog jasena u tresetnom supstratu. $U$ radu su utvrđene glavne morfološke značajke sadnica (visina, promjer vrata korijena i varijable korijenskog sustava).

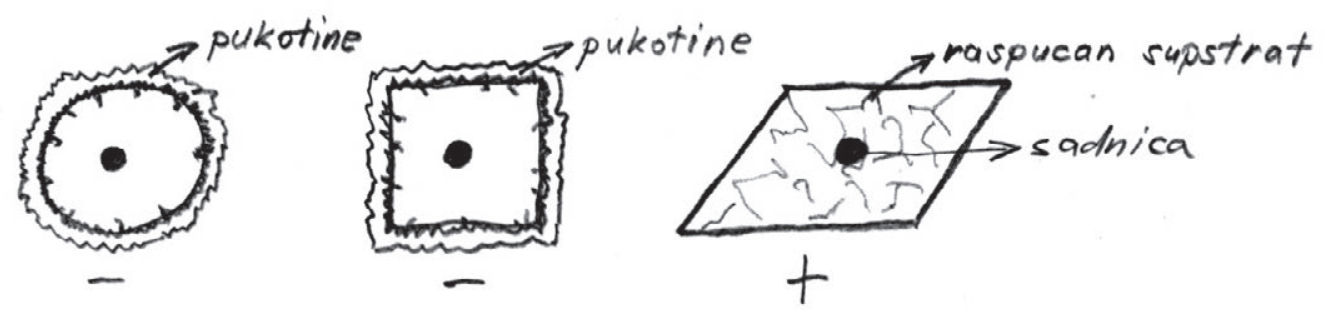

Slika 5. Primjeri loših (-) i dobrog (+) geometrijskog oblika sadne jame (ilustracija: doc. dr. sc. Damir Drvodelić)

Figure 5. Examples of bad (-) and good (+) geometric shapes of a pit (illustration: Damir Drvodelić) 


\section{MATERIJALI I METODE RADA MATERIAL AND METHODS}

Tehnološki postupak uzgoja kontejnerskih sadnica (HICO V-530) poljskog jasena (Fraxinus angustifolia Vahl) $(1+0)$ u rasadniku Brstje, Hrvatske šume d.o.o.

Work technology for growing container seedlings (HICO V-530) of narrow-leaved ash (Fraxinus angustifolia Vahl) $(1+0)$ in Brstje nursery, Hrvatske šume d.o.o.

Supstrat koji se koristi za sjetvu sjemena poljskog jasena u kontejnere HICO V-530 ima trgovački naziv PROFI 1 (ProfiMix la). Riječ je o supstratu za sjetvu, uzgoj biljaka i poboljšanje tla. Supstrat je izrađen po posebnom receptu od ekološki prihvatljivog treseta, poboljšanog aditivima i mikro elementima. Frakcija treseta je fina (od 0 do 5 ili od 0 do 10 $\mathrm{mm}$ ). Strukturu supstrata čini $60 \%$ bijeli A treset, $40 \%$ crni $\mathrm{C}$ treset od 0 do 5 ili od 0 do $10 \mathrm{~mm}$. Sadržaj vlage u supstratu iznosi od 40 do $60 \%$ a pH se kreće od 5,5 do 6,5. Supstrat je oplemenjen s NPK umjetnim gnojivom 14-16-18. Također sadrži i stimulatore za rast korijena naziva Bioroot stimulans. U supstratu ima sredstva za vlaženje naziva Fiba Zorb.

Tablica 1. Glavni parametri određivanja tehnikom ICP-AES

Table 1. Main determination parameters using the ICP-AES technique

Parametar
Parameter
Instrument - Instrument
Snaga RF-a - RF power
Protok rashladnog plina - Coolant gas flow
Protok plina za uzorak - Gas flow for the sample
Protok pomoćnog plina - Auxiliary gas flow
Sustav za uvođenje uzorka - Sampling system
Brzina peristaltičke pumpe - Peristaltic pump speed
Cjevčice peristaltičke pumpe - Peristaltic pump tubes
Vrijeme uvođenja uzorka - Sampling time
Vrijeme ispiranja - Elutriation time
Analiza plazme - Plasma view
Maksimalno vrijeme mjerenja - Maximum measurement time

Maksimalno vrijeme mjerenja-Maximum measurement time

Mjereni elementi i valne duljine $(\mathrm{nm})$ - Measured elements and wavelengths $(\mathrm{nm})$

Kalibracijske otopine - Calibration solutions

Otopina za ispiranje sustava - System elutriate solution
Nakon što je istresen iz vreća (250 1), navedeni supstrat je miješan ručnim alatima. Za dodatnu prihranu je korišteno granulirano gnojivo s postepenim otpuštanjem hranjivih tvari Osmocote exact 15-19-12, u količini od 2,0 g/1 l supstrata. Gnojivo se miješalo sa supstratom na foliji uz pomoć lopata. Punjenje kontejnera supstratima i sjetva sjemena obavljeni su ručno. Sadnice su uzgajane u kontejnerištu rasadnika s projektiranim sustavom navodnjavanja kišenjem.

\section{Kemijske analize supstrata PROFI 1 - Chemical analyses of PROFI 1 substrate}

Kemijske analize supstrata na kojima su uzgojene kontejnerske sadnice poljskog jasena obavljene su u Ekološkopedološkom laboratoriju na Zavodu za ekologiju i uzgajanje šuma Šumarskog fakulteta Sveučilišta u Zagrebu. Za laboratorijske analize korišteni su zrako suhi uzorci tla, prosušeni u laboratoriju, zdrobljeni i prosijani kroz sita promjera otvora 2 i 0,2 mm (ISO 11464, 2004). Na prikupljenim uzorcima izmjereni su sljedeći pedofizigrafski parametri: $\mathrm{pH}$ vrijednost tla $\mathrm{u}_{2} \mathrm{O}$ i $0,01 \mathrm{M}$ otopini $\mathrm{CaCl}_{2}$ (ISO 10390, 2005), udjel karbonata u tlu - volumetrijska metoda (ISO $10693,1995)$, udjel $C_{\text {uk }}$ (ISO 10694, 1995) i udjel $\mathrm{N}_{\text {tot }}$ (ISO 13878, 1995) na uređaju NC Soil Flash 2000 Thermo Sci-

\begin{tabular}{|c|c|}
\hline \multicolumn{2}{|l|}{$\begin{array}{l}\text { Vrijednost } \\
\text { Value }\end{array}$} \\
\hline \multicolumn{2}{|c|}{ Thermo Fischer iCAP6300 Duo } \\
\hline \multicolumn{2}{|l|}{$1150 \mathrm{~W}$} \\
\hline \multicolumn{2}{|l|}{$12 \mathrm{~L} / \mathrm{min}$} \\
\hline \multicolumn{2}{|l|}{$0,65 \mathrm{~L} / \mathrm{min}$} \\
\hline \multicolumn{2}{|l|}{$0,5 \mathrm{~L} / \mathrm{min}$} \\
\hline \multirow{2}{*}{\multicolumn{2}{|c|}{$\begin{array}{l}\text { - automatski uzorkivač CETAC ASX-260 } \\
\text { - koncentrični raspršivač s vrtložnom komorom za raspršivanje } \\
45 \mathrm{okr} / \mathrm{min}\end{array}$}} \\
\hline & \\
\hline \multicolumn{2}{|c|}{$\begin{array}{l}\text { - uzorak: narančasto-bijela } \\
\text { - ispiranje: bijelo-bijela }\end{array}$} \\
\hline \multicolumn{2}{|l|}{$45 \mathrm{~s}$} \\
\hline \multicolumn{2}{|l|}{$60 \mathrm{~s}$} \\
\hline \multicolumn{2}{|c|}{ Automatska (Auto View) } \\
\hline \multicolumn{2}{|c|}{$\begin{array}{l}\text { - niske valne duljine }(160-230 \mathrm{~nm}): 15 \mathrm{~s} \\
\text { - visoke valne duljine }(230-847 \mathrm{~nm}): 5 \mathrm{~s}\end{array}$} \\
\hline \multicolumn{2}{|l|}{$\begin{array}{l}\mathrm{Ca}-393,366 \\
\mathrm{Cu}-324,754\end{array}$} \\
\hline $\mathrm{Fe}-238,204$ & $P-178,284$ \\
\hline $\mathrm{K}-766,490$ & $S-180,731$ \\
\hline $\mathrm{Mg}-279,553$ & $Z n-213,856$ \\
\hline \multicolumn{2}{|l|}{$\mathrm{Mn}-257,610$} \\
\hline \multicolumn{2}{|l|}{$\mathrm{Na}-589,592$} \\
\hline \multicolumn{2}{|c|}{$\begin{array}{l}-0 \mu \mathrm{g} / \mathrm{L} \text { (svi elementi) } \\
-1 \mu \mathrm{g} / \mathrm{L} \text { (sve osim Ca, K, Mg, Na, P, S) } \\
-10 \mu \mathrm{g} / \mathrm{L} \text { (sve osim Ca, K, Mg, Na, P, S) } \\
-100 \mu \mathrm{g} / \mathrm{L}(\text { sve osim, } \mathrm{P} \text { i S) } \\
-2000 \mu \mathrm{g} / \mathrm{L} \mathrm{Ca}, 200 \mu \mathrm{g} / \mathrm{L} \mathrm{K}, 400 \mu \mathrm{g} / \mathrm{L} \mathrm{Mg}, 1000 \mu \mathrm{g} / \mathrm{L} \mathrm{Na} \\
-100 \mu \mathrm{g} / \mathrm{L} \text { (P and S) }\end{array}$} \\
\hline Dušična kiselina & supra pur, $1 \%(v / v)$ \\
\hline
\end{tabular}


entifici. Iz razlike ukupnog ugljika $\left(\mathrm{C}_{\mathrm{uk}}\right)$ i ugljika mineralnog podrijetla $\left(\mathrm{C}_{\text {min }}\right)$ preračunatog iz udjela karbonata iskazan je udjel organskog ugljika (Org C).

\section{Analiza elemenata u tragovima u uzorcima supstrata PROFI 1 - Analysis of trace elements in PROFI 1 substrate samples}

Ekstrakcija elemenata iz uzoraka supstrata priprema uzoraka za određivanje tehnikom ICPAES - Extraction of elements from soil samples - preparing samples for determination using the ICP-AES technique

Ekstrakcija elemenata iz uzoraka supstrata rađena je metodom po Mehlichu III (Mehlich, 1984). Svaki uzorak ( 2,00 $\pm 0,05 \mathrm{~g}$ ) preliven je s $20 \mathrm{~mL}$ otopine Mehlich 3, nakon čega je smjesa mućkana na tresilici ( $200 \mathrm{okr} / \mathrm{min}, 5 \mathrm{~min}$ ). Odjeljivanje ekstrakta od krutog ostatka obavljeno je filtriranjem pomoću papirnatog filtrirnog papira (Wharman No.42). Ekstrakti su čuvani u polipropilenskim scintilacijskim posudicama $(20 \mathrm{~mL})$ u hladnjaku. Za potrebe određivanja kalcija, načinjeno je razrjeđivanje ekstrakata $(100 \times)$ ultračistom vodom. Priređeni ekstrakti analizirani su tehnikom ICP-AES,

Određivanje sadržaja elemenata u tragovima tehnikom ICP-AES - Determining the trace element content by means of the ICP-AES technique

Određivanje sadržaja metala u priređenim uzorcima izvedeno je tehnikom atomske emisijske spektrometrije (ICPAES) uz induktivno spregnutu plazmu. Uređaj je podešen na stabilne uvjete rada te je obavljena vanjska kalibracija serijom standardnih otopina priređenih razrjeđivanjem komercijalnog multielementnog standarda Multi-element Standard Solution koji sadržava $\mathrm{Ag}, \mathrm{Al}, \mathrm{As}, \mathrm{B}, \mathrm{Ba}, \mathrm{Be}, \mathrm{Bi}, \mathrm{Ca}, \mathrm{Cd}$, $\mathrm{Co}, \mathrm{Cr}, \mathrm{Cs}, \mathrm{Cu}, \mathrm{Fe}, \mathrm{In}, \mathrm{K}, \mathrm{Li}, \mathrm{Mg}, \mathrm{Mn}, \mathrm{Mo}, \mathrm{Na}, \mathrm{Ni}, \mathrm{Nb}, \mathrm{Pb}, \mathrm{Rb}$, $\mathrm{Sb}, \mathrm{Se}, \mathrm{Sr}, \mathrm{Ti}, \mathrm{Tl}, \mathrm{V}, \mathrm{U}, \mathrm{Zn}\left(100 \pm 0.2 \mathrm{mg} \mathrm{L}^{-1}, 5 \% v / v \mathrm{HNO}_{3}\right)$, C.P.A. Chem, Bulgaria. Uz to, standardna otopina za kalibraciju $\mathrm{P}$ iS priređena je razrjeđivanjem Multi-element Standard Solution koji sadrži P i S $\left(100 \pm 0.2 \mathrm{mg} \mathrm{L}^{-1}\right)$, C.P.A.
Chem, Bulgaria. Za elemente $\mathrm{Na}, \mathrm{K}, \mathrm{Mg}$ i Ca korištena je komercijalna standardna otopina Multielement standard solution III for ICP, TraceCERT" (Fluka). Spomenute standardne otopine razrjeđivane su otopinom Mehlich III, tj. napravljena je matrično-prilagođena vanjska kalibracija.U tablici 1 . su dani važni parametri instrumentalne analize.

Određivanje morfoloških osobina kontejnerskih sadnica (HICO V-530) poljskog jasena poljskog jasena (Fraxinus angustifolia Vahl) $(1+0)$ koje su pošumljene na području šumarije Lipovljani u jesen 2017. godine a uzgojene u rasadniku Brstje, Hrvatske šume d.o.o. - Determining morphological properties of container seedlings (HICO V-530) of narrow-leaved ash (Fraxinus angustifolia Vahl) $(1+0)$, which were planted in the area of Lipovljani Forest Office in the autumn of 2017 and raised in Brstje nursery, Hrvatske šume d.o.o.

Najznačajnije morfološke osobine kontejnerskih sadnica poljskog jasena (visina izbojka i promjer vrata korijena) te morfološke osobine korijenskog obavljene su u Laboratoriju za šumsko sjemenarstvo i rasadničarstvo na Zavodu za ekologiju i uzgajanje šuma Šumarskog fakulteta Sveučilišta u Zagrebu. Iz svakog kontejnera izvađena je po 1 sadnica za morfološku analizu korijenskog sustava. Nakon detaljnog ispiranja supstrata sa korijena, pomoću skenera Epson Expression 10000XL i softwera WinRHIZO ProLA2400 (2005) za analizu opranog korijena, utvrdilo se 28. značajnijih morfoloških varijabli korijenskog sustava prikazanih u tablici 5.

\section{REZULTATI}

\section{RESULTS}

U tablici 2. prikazani su podaci kemijske analize supstrata korištenog kod kontejnerske proizvodnje sadnica (HICO V-530) poljskog jasena (Fraxinus angustifolia Vahl) $(1+0)$ koje su pošumljene na području šumarije Lipovljani u jesen 2017. godine a uzgojene u rasadniku Brestje, Hrvatske šume d.o.o.

Tablica 2. Kemijske značajke u supstratu za uzgoj kontejnerskih sadnica (HICO V-530) poljskog jasena $(1+0)$ koje su pošumljene na području šumarije Lipovljani u jesen 2017. godinea uzgojene u šumskom rasadniku Brestje, Hrvatske šume d.o.0.

Table 2. Chemical characteristics of substrates for the production of container seedlings (HICO V-530) of narrow-leaved ash (Fraxinus angustifolia Vahl) $(1+0)$, which wereplanted in the area of Lipovljani Forest Office in the autumn of 2017 and grown in "Brestje" forest nursery, Hrvatske šume d.0.0.

\begin{tabular}{|c|c|c|c|c|c|c|c|c|}
\hline $\begin{array}{l}\text { Varijabla } \\
\text { Variable }\end{array}$ & $\begin{array}{c}\text { Jedinica } \\
\text { Unit }\end{array}$ & $\begin{array}{c}\text { Broj uzoraka } \\
\text { Number of samples }\end{array}$ & $\begin{array}{l}\text { Aritm. sred. } \\
\text { Mean }\end{array}$ & $\begin{array}{l}\text { Medijan } \\
\text { Median }\end{array}$ & $\begin{array}{l}\text { Minimum } \\
\text { Minimum }\end{array}$ & $\begin{array}{l}\text { Maksimum } \\
\text { Maximum }\end{array}$ & $\begin{array}{l}\text { Std. dev. } \\
\text { Std. Dev. }\end{array}$ & $\begin{array}{c}\text { Koef. varijacije } \\
\text { Coefficient of variation }\end{array}$ \\
\hline $\mathrm{pH}_{\mathrm{H} 20}$ & - & 5 & 6,66 & 6,60 & 6,58 & 6,87 & 0,12 & 1,80 \\
\hline $\mathrm{pH}_{\mathrm{CaCl} 2}$ & - & 5 & 6,01 & 6,05 & 5,86 & 6,20 & 0,14 & 2,30 \\
\hline $\mathrm{CaCO}_{3}$ & $\mathrm{~g} \mathrm{~kg}^{-1}$ & 5 & 9,95 & 9,62 & 9,39 & 11,14 & 0,74 & 7,45 \\
\hline Org C & $\%$ & 5 & 60,50 & 60,98 & 58,66 & 61,22 & 1,08 & 1,78 \\
\hline N uk & $\%$ & 5 & 1,78 & 1,78 & 1,73 & 1,83 & 0,04 & 2,09 \\
\hline $\mathrm{C} / \mathrm{N}$ & - & 5 & 34,48 & 34,54 & 33,05 & 35,86 & 1,04 & 3,02 \\
\hline
\end{tabular}


Tablica 3. Udjel makro i mikro hranjiva u supstratu za uzgoj kontejnerskih sadnica (HICO V-530) poljskog jasena (Fraxinus angustifolia Vahl) (1+0) koje su pošumljene na području šumarije Lipovljani u jesen 2017. godine ekstrahiran Mechlich-3 otopinom (M3).

Table 3. Macro and micro nutrient parts in the substrate for the production of container seedlings (HICO V-530) of narrow-leaved ash (Fraxinus angustifolia Vahl) (1+0), which were used to afforest the area of Lipovljani Forest Office in the autumn of 2017 and grown in the forest nursery of "Brestje" and extracted with Mechlich-3 solution (M3).

$\begin{array}{ccccccccc}\begin{array}{c}\text { Varijabla } \\ \text { Variable }\end{array} & \begin{array}{c}\text { Jedinica } \\ \text { Unit }\end{array} & \begin{array}{c}\text { Broj uzoraka } \\ \text { Number of samples }\end{array} & \begin{array}{c}\text { Aritm. sred. } \\ \text { Mean }\end{array} & \begin{array}{c}\text { Medijan } \\ \text { Median }\end{array} & \begin{array}{c}\text { Minimum } \\ \text { Minimum }\end{array} & \begin{array}{c}\text { Maksimum } \\ \text { Maximum }\end{array} & \begin{array}{c}\text { Std. dev. } \\ \text { Std. Dev. }\end{array} & \begin{array}{c}\text { Koef. varijacije } \\ \text { Coefficient of variation }\end{array} \\ \mathrm{P}_{2} \mathrm{O}_{5}-\mathrm{M} 3 & \mathrm{mg} \mathrm{kg}^{-1} & 5 & 38,00 & 0,14 & 0,14 & 123,09 & 55,57 & 146,24 \\ \mathrm{P}_{2} \mathrm{O}_{5}-\mathrm{AL} & \mathrm{mg} \mathrm{kg}^{-1} & 5 & 43,82 & 12,13 & 12,13 & 115,04 & 46,51 & 106,15 \\ \mathrm{~K}_{2} \mathrm{O}-\mathrm{M} 3 & \mathrm{mg} \mathrm{kg}^{-1} & 5 & 35,94 & 5,84 & 2,06 & 121,56 & 51,56 & 143,48 \\ \mathrm{~K}_{2} \mathrm{O}-\mathrm{AL} & \mathrm{mg} \mathrm{kg}^{-1} & 5 & 32,92 & 7,10 & 3,85 & 106,39 & 44,24 & 134,37 \\ \mathrm{~S} & \mathrm{mg} \mathrm{kg}^{-1} & 5 & 42,02 & 4,63 & 2,16 & 121,14 & 54,93 & 130,73 \\ \mathrm{Ca} & \mathrm{mg} \mathrm{kg}^{-1} & 4 & 6104,59 & 6655,59 & 218,07 & 10889,10 & 4472,25 & 73,26 \\ \mathrm{Mg} & \mathrm{mg} \mathrm{kg}^{-1} & 2 & 734,10 & 734,10 & 654,57 & 813,64 & 112,47 & 15,32 \\ \mathrm{Fe} & \mathrm{mg} \mathrm{kg}^{-1} & 5 & 101,37 & 21,98 & 7,99 & 247,44 & 120,82 & 119,19 \\ \mathrm{Zn} & \mathrm{mg} \mathrm{kg}^{-1} & 5 & 3,62 & 0,34 & 0,34 & 12,46 & 5,27 & 145,78 \\ \mathrm{Mn} & \mathrm{mg} \mathrm{kg}^{-1} & 5 & 10,49 & 2,09 & 0,92 & 29,27 & 12,97 & 123,59 \\ \mathrm{Cu} & \mathrm{mg} \mathrm{kg}^{-1} & 5 & 4,53 & 0,87 & 0,24 & 11,94 & 5,66 & 125,09\end{array}$

Iz tablice 1. vidljivo je kako je $\mathrm{pH}$ supstrata kod kontejnerskih sadnica u $\mathrm{H}_{2} \mathrm{O}$ i $\mathrm{CaCl}_{2}$ bio homogen s obzirom na pojedini otvor multikontejnera. Udio $\mathrm{CaCO}_{3}$ je nizak i kreće se oko $1 \mathrm{~g} / \mathrm{kg}$. Odnos $\mathrm{C} / \mathrm{N}$ je povišen što ukazuje na slabiju razgradnju supstrata nakon sadnje, posebno ako su klimatski uvjeti nepovoljni (manjak vlage tijekom ljeta i visoke temperature ili s druge strane pretjerana zasićenost supstrata s vodom. Odnos $\mathrm{C} / \mathrm{N}$ trebao bi biti niži i kretati se oko 20:1. Supstrat je bio čistog organskog porijekla, u njemu nisu pronađeni ostaci gnojiva (npr. prazni omotači od biljne smole kod gnojiva s produženim djelovanjem tipa Osmocote i sl.). Sastav organskog supstrata pokazuje vrlo visoku homogenost što i odgovara navodima proizvođača. Raspon $\mathrm{pH}$ vrijednosti također je u navedenim vrijednostima između 5,5 i 6,5. Udjel vode u uzorcima je bio između 18 i $19 \%$.

\section{Sažeta analiza rezultata udjela makro i mikro hranjiva u supstratu PROFI 1 korištenog kod uzgoja kontejnerskih sadnica (HICO V-530) poljskog jasena (Fraxinus angustifolia Vahl) $(1+0)$ koje su pošumljene na području šumarije Lipovljani u jesen 2017. godine - Summarized analysis of the results of macro and micro nutrient proportion in PROFI 1}

\section{substrate used for the production of container seedlings (HICO V-530) of narrow-leaved ash (Fraxinus angustifolia Vahl) $(1+0)$, which were planted in the area of Lipovljani Forest Office in the autumn of 2017}

Da bi se mogla interpretirati opskrbljenost fosforom $\left(\mathrm{P}_{2} \mathrm{O}_{5}\right)$ i kalijem $\left(\mathrm{K}_{2} \mathrm{O}\right)$ prema (Vukadinović i Vukadinović, 2011) rezultati dobiveni ekstrakcijom $\mathrm{M} 3$ regresijskim jednadžbama prevedeni su u odgovarajuće vrijednosti dobivene po AL metodi (najčešće upotrebljavana metoda u Republici Hrvatskoj). Dobiveni rezultati ukazuju na vrlo nisku opskrbljenost fosforom i kalijem. Treba istaknuti da za sva analizirana hranjiva postoji vrlo visoka varijabilnost (koeficijent varijacije je iznad $100 \%$ ) što ukazuje da nije postignuta zadovoljavajuća homogeniziranost supstrata u kontejnerima.

Korigiran je udjel organskog ugljika za udjel vode i udjel mineralnog $\mathrm{C}$, a udjel dušika za udjel vode pa su isti izbačeni, a vrijednosti za Org C i uk N drugačije. Fosfor i kalij izraženi su kao $\mathrm{P}_{2} \mathrm{O}_{5}$ i $\mathrm{K}_{2} \mathrm{O}$ kako je najčešće uvriježeno $\mathrm{u}$ pedologiji i ishrani i to je svedeno na AL metodu koja je u neku ruku najčešće upotrebljavana u Republici Hrvatskoj. Opskrbljenost je niska, a supstrat nehomogen. Homogena je samo organska komponenta (treset).

Tablica 4. Deskriptivna statistika visina i promjera vrata korijena kontejnerskih sadnica (HICO V-530) poljskoga jasena (Fraxinus angustifolia Vahl) $(1+0)$ koje su pošumljene na području šumarije Lipovljani u jesen 2017. godine

Table 4. Descriptive statistics of heights and root collar diameters of container seedlings (HICO V-530) of narrow-leaved ash (Fraxinus angustifolia Vahl) $(1+0)$, which were planted in the area of Lipovljani Forest Office in the autumn of 2017

\begin{tabular}{lcccccc}
\multicolumn{1}{c}{$\begin{array}{c}\text { Varijable } \\
\text { Variables }\end{array}$} & $\begin{array}{c}\text { Aritm. sred. } \\
\text { Mean }\end{array}$ & $\begin{array}{c}\text { Medijan } \\
\text { Median }\end{array}$ & $\begin{array}{c}\text { Minimum } \\
\text { Minimum }\end{array}$ & $\begin{array}{c}\text { Maksimum } \\
\text { Maximum }\end{array}$ & $\begin{array}{c}\text { Varijanca } \\
\text { Variance }\end{array}$ & $\begin{array}{c}\text { Std. dev. } \\
\text { Std.Dev. }\end{array}$ \\
$\begin{array}{l}\text { Visina }(\mathrm{cm}) \\
\text { Height }(\mathrm{cm})\end{array}$ & 21 & 21 & 21 & 24 & 3 & 2 \\
$\begin{array}{l}\text { Promjer vrata korijena }(\mathrm{mm}) \\
\text { Roor collar diameter }(\mathrm{mm})\end{array}$ & 4,52 & 4,51 & 3,70 & 5,28 & 0,34 & 0,58
\end{tabular}


Tablica 5. Deskriptivna statistika značajnijih morfoloških varijabli opranog korijenskog sustava kontejnerskih sadnica (HICO V-530) poljskoga jasena (Fraxinus angustifolia Vahl) $(1+0)$ koje su pošumljene na području šumarije Lipovljani u jesen 2017. godine

Table 5. Descriptive statistics of the most important morphological variables of a washed root system of container seedlings (HICO V-530) of narrowleaved ash (Fraxinus angustifolia Vahl) (1+0), which were planted in the area of Lipovljani Forest Office in the autumn of 2017

\begin{tabular}{|c|c|c|c|c|c|c|}
\hline $\begin{array}{l}\text { Varijable } \\
\text { Variables }\end{array}$ & $\begin{array}{l}\text { Aritm. sred. } \\
\text { Mean }\end{array}$ & $\begin{array}{l}\text { Medijan } \\
\text { Median }\end{array}$ & $\begin{array}{l}\text { Minimum } \\
\text { Minimum }\end{array}$ & $\begin{array}{l}\text { Maksimum } \\
\text { Maximum }\end{array}$ & $\begin{array}{l}\text { Varijanca } \\
\text { Variance }\end{array}$ & $\begin{array}{l}\text { Std. dev. } \\
\text { Std.Dev. }\end{array}$ \\
\hline $\begin{array}{l}\text { Duljina }(\mathrm{cm}) \\
\text { Length }(\mathrm{cm})\end{array}$ & 826,51 & 858,59 & 682,95 & 992,76 & 18674,38 & 136,65 \\
\hline $\begin{array}{l}\text { Projicirana površina }\left(\mathrm{cm}^{2}\right) \\
\text { Projection area }\left(\mathrm{cm}^{2}\right)\end{array}$ & 89,05 & 88,95 & 68,84 & 106,83 & 298,83 & 17,29 \\
\hline $\begin{array}{l}\text { Površina }\left(\mathrm{cm}^{2}\right) \\
\text { Area }\left(\mathrm{cm}^{2}\right)\end{array}$ & 279,75 & 279,43 & 216,25 & 335,60 & 2949,38 & 54,31 \\
\hline $\begin{array}{l}\text { Prosječan promjer }(\mathrm{mm}) \\
\text { Average diameter }(\mathrm{mm})\end{array}$ & 1,07 & 1,06 & 1,01 & 1,18 & 0,00 & 0,06 \\
\hline $\begin{array}{l}\text { Volumen }\left(\mathrm{cm}^{3}\right) \\
\text { Volume }\left(\mathrm{cm}^{3}\right)\end{array}$ & 7,56 & 7,24 & 5,45 & 9,87 & 3,20 & 1,79 \\
\hline $\begin{array}{l}\text { Vrhovi (kom) } \\
\text { Tips (pcs) }\end{array}$ & 217 & 214 & 185 & 249 & 923 & 30 \\
\hline $\begin{array}{l}\text { Račvanja (kom) } \\
\text { Forks (pcs) }\end{array}$ & 2667 & 2762 & 1984 & 3276 & 372393 & 610 \\
\hline $\begin{array}{l}\text { Križanja (kom) } \\
\text { Crossings (pcs) }\end{array}$ & 983 & 1046 & 732 & 1241 & 50485 & 225 \\
\hline $\begin{array}{l}0.000<\text { duljina }<=1.000 \\
0.000<\text { length }<=1.000\end{array}$ & 625,89 & 647,85 & 531,19 & 752,80 & 8519,44 & 92,30 \\
\hline $\begin{array}{l}1.000<\text { duljina }<=2.000 \\
1.000<\text { length }<=2.000\end{array}$ & 128,17 & 137,70 & 95,37 & 159,90 & 924,11 & 30,40 \\
\hline $\begin{array}{l}2.000<\text { duljina }<=5.000 \\
2.000<\text { length }<=5.000\end{array}$ & 61,18 & 49,94 & 43,70 & 97,20 & 484,04 & 22,00 \\
\hline $\begin{array}{l}\text { duljina }>5.000 \\
\text { length }>5.000\end{array}$ & 10,32 & 11,50 & 3,94 & 12,35 & 12,90 & 3,59 \\
\hline $\begin{array}{l}0.000<\text { površina }<=1.000 \\
0.000<\text { area }<=1.000\end{array}$ & 76,97 & 80,24 & 65,78 & 91,38 & 114,61 & 10,71 \\
\hline $\begin{array}{l}1.000<\text { površina }<=2.000 \\
1.000<\text { area }<=2.000\end{array}$ & 55,43 & 59,12 & 40,84 & 69,34 & 186,20 & 13,65 \\
\hline $\begin{array}{l}2.000<\text { površina. }<=5.000 \\
2.000<\text { area }<=5.000\end{array}$ & 55,47 & 44,48 & 40,90 & 90,45 & 429,95 & 20,74 \\
\hline $\begin{array}{l}\text { površina }>5.000 \\
\text { area }>5.000\end{array}$ & 20,75 & 23,95 & 7,22 & 24,72 & 57,57 & 7,59 \\
\hline $\begin{array}{l}0.000<\text { projicirana površina }<=1.000 \\
0.000<\text { projection area }<=1.000\end{array}$ & 24,50 & 25,54 & 20,94 & 29,09 & 11,61 & 3,41 \\
\hline $\begin{array}{l}1.000<\text { projicirana površina }<=2.000 \\
1.000<\text { projection area }<=2.000\end{array}$ & 17,64 & 18,82 & 13,00 & 22,07 & 18,87 & 4,34 \\
\hline $\begin{array}{l}2.000<\text { projicirana površina }<=5.000 \\
2.000<\text { projection area }<=5.000\end{array}$ & 17,66 & 14,16 & 13,02 & 28,79 & 43,56 & 6,60 \\
\hline $\begin{array}{l}\text { projicirana površina }>5.000 \\
\text { projection area }>5.000\end{array}$ & 6,60 & 7,62 & 2,30 & 7,87 & 5,83 & 2,42 \\
\hline $\begin{array}{l}0.000<\text { volumen }<=1.000 \\
0.000<\text { volume }<=1.000\end{array}$ & 1,01 & 1,07 & 0,85 & 1,19 & 0,02 & 0,14 \\
\hline $\begin{array}{l}1.000<\text { volumen }<=2.000 \\
1.000<\text { volume }<=2.000\end{array}$ & 1,99 & 2,10 & 1,45 & 2,49 & 0,26 & 0,51 \\
\hline $\begin{array}{l}2.000<\text { volumen }<=5.000 \\
2.000<\text { volume }<=5.000\end{array}$ & 4,29 & 3,51 & 3,13 & 7,18 & 2,82 & 1,68 \\
\hline $\begin{array}{l}\text { volumen }>5.000 \\
\text { volume }>5.000\end{array}$ & 3,45 & 3,80 & 1,06 & 4,59 & 1,89 & 1,37 \\
\hline $\begin{array}{l}0.000<\text { vrhovi }<=1.000 \\
0.000<\text { tips }<=1.000\end{array}$ & 214 & 210 & 182 & 247 & 886 & 30 \\
\hline $\begin{array}{l}1.000<\text { vrhovi }<=2.000 \\
1.000<\text { tips }<=2.000\end{array}$ & 1 & 1 & 0 & 3 & 2 & 1 \\
\hline $\begin{array}{l}2.000<\text { vrhovi }<=5.000 \\
2.000<\text { tips }<=5.000\end{array}$ & 1 & 1 & 0 & 2 & 1 & 1 \\
\hline $\begin{array}{l}\text { vrhovi }>5.000 \\
\text { tips }>5.000\end{array}$ & 1 & 1 & 0 & 2 & 1 & 1 \\
\hline
\end{tabular}




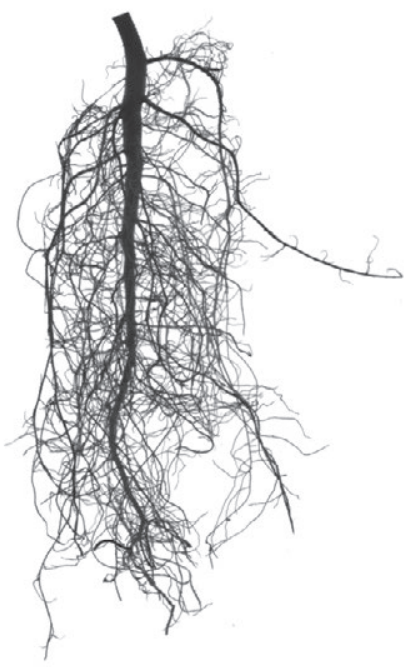

Slika 6. Oprani korijenski sustav kontejnerskih sadnica (HICO V-530) poljskog jasena (Fraxinus angustifolia Vahl) $(1+0)$

Figure 6. Washed root system of a container seedling (HICO V-530) of narrow-leaved ash (Fraxinus angustifolia Vahl) $(1+0)$

U tablici 4. prikazana je deskriptivna statistika visina i promjera vrata korijena kontejnerskih sadnica (HICO V-530) poljskoga jasena (Fraxinus angustifolia Vahl) $(1+0)$ koje su pošumljene na području šumarije Lipovljani u jesen 2017. godine
Pošumljene kontejnerske sadnice imale su prosječnu visinu od $21 \mathrm{~cm}$ i promjer vrata korijena od 4,52 cm. Šumska sadnica ne smije ići na teren iz rasadnika ukoliko ima visinu manju od $15 \mathrm{~cm}$ što u ovim istraživanjima nije bio slučaj.

U tablici 5. prikazana je deskriptivna statistika značajnijih morfoloških varijabli opranog korijenskog sustava kontejnerskih sadnica (HICO V-530) poljskoga jasena (Fraxinus angustifolia Vahl) $(1+0)$ koje su pošumljene na području šumarije Lipovljani u jesen 2017. godine.

Na slici 6. prikazan je uzorak opranog korijenskog sustava prosječne kontejnerske sadnice (HICO V-530) poljskog jasena (Fraxinus angustifolia Vahl) $(1+0)$ po visini

Korijenski sustav ima glavnu žilu koja raste pozitivno geotropno i niz korijenskih žila koje rastu također pozitivno geotropno s različitih stupnjem otklona od glavne žile. Korijen ima prikladan sustav razgranjenja s obzirom na tip i veličinu kontejnera te dob sadnice. Na slici nisu vidljive deformacije korijenskog sustava.

Na slici 7. prikazana je analiza opranog korijena uz pomoć softwera WinRHIZO ProLA2400 (2005)

$\mathrm{Na}$ softverskom prikazu vidi se puno sitnih korjenčića ukupne srednje duljine od $826,51 \mathrm{~cm}$ pri čemu posebno veliki udio od $625,89 \mathrm{~cm}$ ili $75,73 \%$ imaju najtanji kor-

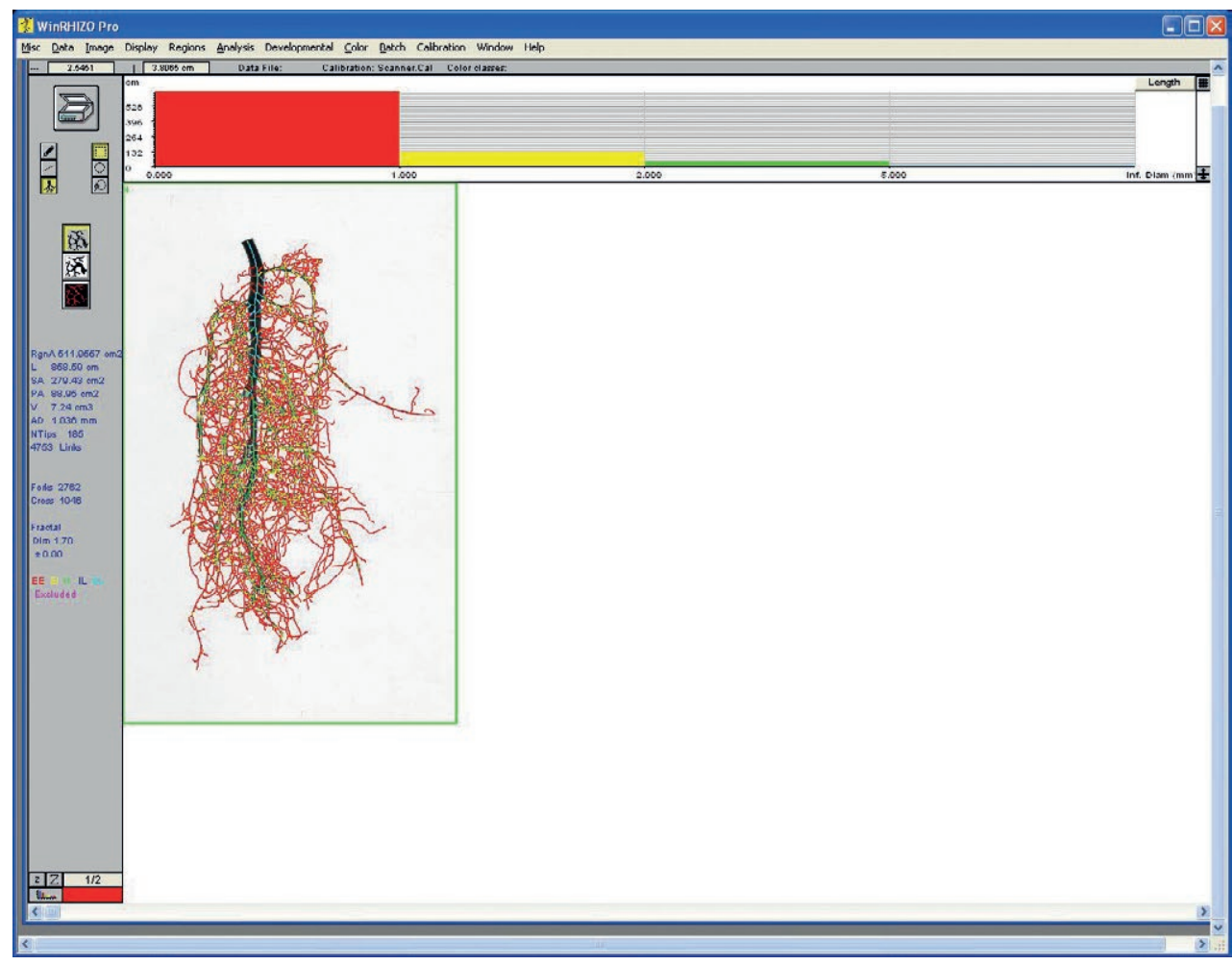

Slika 7. Analiza opranog korijena sa slike 6. kontejnerske sadnice (HICO V-530) poljskog jasena $(1+0)$ uz pomoć softwera WinRHIZO ProLA2400 (2005)

Figure 7. Analysis of a washed root of container seedling (HICO V-530) of narrow-leaved ash (Fraxinus angustifolia Vahl) (1+0) from Figure 6 using WinRHIZO ProLA2400 software (2005) 
jenčići promjera od 0.000 do $1.000 \mathrm{~cm}$ (tablica 4). Iz iste tablice je vidljivo kako ukupna srednja duljina korjenčića pada s povećanjem njihovih promjera.

\section{RASPRAVA I ZAKLJUČCI DISCUSSION AND CONCLUSSION}

Za očekivati je kako bi presadnja sadnica poljskoga jasena u kontinentalnom dijelu Republike Hrvatske krajem ljeta i početkom jeseni trebala dati puno bolje rezultate u odnosu na proljetnu presadnju. Sadnju treba obaviti nakon dva tjedna što sve lišće otpadne s jasenovih sadnica u rasadniku. O tome treba brigu voditi tehnolog proizvodnje. Jasen ima svojstvo kasnog listanja i ranog odbacivanja lišća u kratkom vremenskom razdoblju. Kada se sadnice sa smanjenom transpiracijom posade na teren, a povoljni uvjeti potiču rast korijena, biljka se brže ukorjenjuje u okolno tlo što je najvažnije.

Cambi i dr. (2018) pišu o negativnom utjecaju na rast biljaka i mehaničkog otpora ukoliko je vrijednost otpora na penetrometru veća od 2,5 MPa. Vodo propusnost tla može se izmjeriti praktično vrlo jednostavnom metodom. $\mathrm{U}$ tlu se iskopa rupa i zalije s 21 vode, prvi i drugi put se pusti da tlo upije vodu, a treći put se mjeri vrijeme propustljivosti vode.

Unatoč poznatoj činjenici kako zbijenost tla utječe na razvoj klijanca $\mathrm{i}$ korijenskog sustava, ona se počela značajnije istraživati unazad dva desetljeća. Utvrđeno je kako se s povećanjem zbijenosti tla klijavost sjemena hrasta lužnjaka statistički značajno usporava. Osim na klijavost sjemena, zbijenost tla negativno utječe na morfološke značajke nadzemnog i podzemnog dijela sadnica i može utjecati na uspjeh prirodne obnove, posebno kada nepovoljni uvjeti rasta (suša ili oštra klima) mogu biti daljnja prepreka za razvoj klijanca. Mnogi autori proučavaju utjecaj sabijenosti tla na visine sadnica hrasta lužnjaka na kraju prve vegetacije te utvrđuju negativni utjecaj sabijanja. Kod nekih drugih vrsta (smreke, borovi), sabijanje nije značajno utjecalo na visine sadnice već na značajke korijenskog sustava. Kada je struktura tla utjecana sječom stabala (dovršnim sijekom) koji uzrokuje sabijanje tla, događa se proces degradacija tla i/ili se povećava što dovodi do daljnjih problema u obnovi šuma. Kod gospodarenja šumama bliskoj prirodi ili pod stalnim zastorom krošanja, uspjeh prirodne obnove nakon dovršnog sijeka je od presudne važnosti kako bi se izbjegla degradacija staništa i potaknuo brzi oporavak tla. Vjerojatno bi se negativan utjecaj zbijenosti tla na klijavost sjemena i morfološke značajke sadnica pokazao i sa sjemenom poljskog jasena bilo u slučaju proizvodnje sadnica gologa ili obloženoga korijena ili umjetne obnove sjetvom sjemena zbog izostanka uroda. Zbijenost tla ima značajan utjecaj na korijenski sustav, naročito njegov rast u dubinu te na visinu izbojka. Zbijenost tla može utjecati na zakorjenjivanje sadnica. Ozbiljni problemi u razvoju korijenskog sustava mogu se po- javiti kada poroznost tla ne dopušta prodiranje sitnog korijenja. Dobro je poznato kako zbijena tla zadržavaju više vode pri poljskom kapacitetu tla za vodu od nezbijenih tala. $\mathrm{U}$ zbijenim tlima, visoki postotak finih pora može tako čvrsto vezati vodu da ju korijen biljke ne može usvojiti. Dublje zakorjenjene sadnice imaju veću vjerojatnost za preživljavanje tijekom ljetne suše za razliku od sadnica s plićim korijenskim sustavom iz čega proizlazi da korijenski sustav sadnica (volumen) ima važnu ulogu u preživljavanju biljaka.

Kontejnerske sadnice u praksi se uzgajaju u čistom organskom mediju poput crnog treseta koji je nepoželjan jer se nakon sadnje treset tijekom ljeta, kad nastupe visoke temperature, lako isušuje i ako mu sadržaj vlage padne ispod $34 \%$ on više neće upijati vodu (postaje vodni repelent) već se ona procjeđuje oko korijena u supstratu i on ugiba zbog manjka vlage. O primjeni gnojiva Osmocote na uspijevanje i kvalitetu sadnica poljskog jasena (Fraxinus angustifolia Vahl) uzgajanog u kontejnerima od tvrde plastike piše Komlenović (1997) i navodi kako je površinski primijenjeno gnojivo Osmocote pozitivno utjecalo na uspijevanje jasenovih biljaka uzgajanih na supstratima od treseta iz Latvije i Mađarske, a posebno iz Latvije. Rast biljaka se povećavao s porastom doze gnojiva.

Uzroci velikog mortaliteta sadnica poljskog jasena kod pošumljavanja na području Republike Hrvatske - Causes of high mortality of narrow-leaved ash (Fraxinus angustifolia Vahl) seedlings during reforestation in the area of Republic of Croatia

Sadnice golog korijena uzgajaju se u našim rasadnicima najčešće na istim proizvodnim površinama. Zbog intenzivnog uzgoja tla su degradirana, izgubljen je balans između određenih makro i mikro biljnih hranjiva u tlu, pa je povećana količina klora i salinitet. Rasadnička tla uglavnom imaju deficit humusa. Trebalo bi koristiti gnojiva visoke kakvoće bez klora, termostabilna, s dodatkom mikroelemenata i huminskih kiselina. Kod monokulturnog uzgoja šumskih sadnica s godinama se značajno povećava količina patogenih bolesti, a time i korištenje velikih količina sredstava za zaštitu. Kontejnerske sadnice često se uzgajaju u neodgovarajućem supstratu s isključivo sporootpuštajućim gnojivima, koja u našim mikroklimatskim uvjetima često u praksi neravnomjerno i puno brže otpuštaju hranjiva. Trebalo bi obavljati prihranjivanje kroz sustav navodnjavanja (fertirigacija), prilagođenu fenofazama sadnica. Posljedica gore navedenog su sadnice siromašne hranjivima, s premalim zalihama fosfora i kalija za zimsko mirovanje i početni rast korijenja, te kretanje vegetacije. Jako niska razina enzima, hormona rasta (auksin) i fenola uzrokuje podložnost svim gljivičnim i bakterijskim bolestima, te slabu otpornost na stres (presadnja, temperatura, vlaga...). Nakon dovršnog sijeka u šumskoj sastojini ostaje velika količina svježe organske materije, koja za raspadanje treba velike količine 
dušika. U odjelima nema stabala koje bi tijekom poplava opskrbljivalo mikorizne gljive i tlo kisikom, pa se mikrobiološki život značajno smanjuje. Teška ilovasta tla su zbijena, pa nastaju štetni anaerobni procesi fermentacije. Kasnoproljetna sadnja u jako mokro tlo rezultira time da je biljka "gladna“ (razni fiziološki poremećaji) i ne uspijeva se ukorijeniti u matično tlo. Vrlo brzo dolaze visoke temperature i duga razdoblja suše, pa loše pripremljeno tlo i sadna jama sa zračnim džepovima rezultira pucanjem tla i korijenja, te sušenjem sadnica. $S$ druge strane, višak padalina u toplom razdoblju ubrzava porast patogenih i anaerobnih mikroorganizama, što rezultira propadanjem sadnica. Radi stabilizacije dušika preporučuje se maknuti svježu organsku tvar sa sadnog mjesta. Radi obnove mikroflore u tlu i biozaštite preporučuje se primjena ektomikoriznih cjepiva i entomopatogenih gljiva. Dobra šumarska praksa iz srednje Europe i Skandinavije uključuje:

- izvoz granjevine i biomase

- kopanje meliorativnih kanala kako bi se poplavna voda brže povlačila

- riperanje tla kako bi se razbio nepropusni horizont (taban) u tlu nastao dugim stajanjem vode visokog nivoa koje fizički sabija i degradira tlo

- strojna priprema sadnih mjesta (kako bi se uklonio organski otpad)

- pravilna sadnja sadnica gologa i obloženoga korijena (prikazana na ilustracijama)

- obavezna mikorizacija

- močenje korijenja sadnica u vodotopivim gnojivima s aktivatorima rasta (auksini, huminske kiseline...)

- startna gnojidba (stavljanjem gnojiva u obliku tablete uz sadnicu)

- organska gnojidba (digestat iz bioplinskih postrojenja, mulj iz kanala za meliorizaciju i ribnjaka, mulj iz pročišćivača otpadnih voda, kompost od biootpada)

- sadnja manje količine sadnica po hektaru ali s tulijevim cijevima, naročito na vlažnim, močvarnim i plavljenim terenima gdje led uzrokuje savijanje sadnica

\section{LITERATURA}

\section{REFERENCES}

- Adams, J. C., W. B. Patterson, 2004: Comparison of planting bar and hoedad planted seedlings for survival and growth in a controlled environment. In: Connor KF, editor Proceedings of the 12th Biennial Southern Silvicultural Research Conference. Asheville (NC):USDA-Forest Service, Southern Research Station. General Technical Report GTR SRS-71: 423.-424.

- Balneaves, J. M., Menzies, M. I. 1988: Lifting and handling procedures at Edendale Nursery-effects on survival and growth of 1/0 Pinus radiata seedlings. New Zealand Journal of Forestry Science, 18:132.-134.

- Blake, J. I., L. D. Teeter, D. B. South, 1989: Analysis of the economic benefits from increasing uniformity in Douglas-fir nurs- ery stock. In: Mason, W. L., J. D. Deans, and S. Thompson, editors. Producing uniform conifer planting stock. Forestry Supplement 62: 251.-262.

- Bobinec Mikek, D., 2009: Utjecaj potencijala rasta korijena sadnica crnog bora (Pinus nigra F. J. Arnold) na njihovo preživljavanje. Magistarski rad. Sveučilište u Zagrebu, Šumarski fakultet. 180. str.

- Burr, K. E., 1990: The target seedling concepts: bud dormancy and cold hardiness. In: R. Rose, S. J. Campbell, T. D. Landis, editors. Target seedling symposium: combined proceedings of the western forest nursery associations; 1990 August 13-17; Roseburg, OR. Fort Collins (CO): USDA Forest Service, Rocky Mountain Forest and Range Experiment Station. General Technical Report RM-200: 79.-90. str.

- Burr, K. E., R. W. Tinus, S. J. Wallner, R. M. King, 1990: Comparison of three cold hardiness tests for conifer seedlings. Tree Physiology, 6: 351.-369.

- Cambi, M., B. Mariotti, F. Fabiano, A. Maltoni, A. Tani, C. Foderi, A. Laschi, E. Marchi, 2018: Early response of Quercus robur seedlings to soil compaction following germination. Land Degrad Dev., 29: 916.-925.

- Cleary, B. D., J. B. Zaerr, 1980: Pressure chamber techniques for monitoring and evaluating seedling water status. New Zealand Journal of Forest Science, 10:133.-141.

- Crnković, S., D. Drvodelić, S. Perić, 2017: Morfološke značajke kontejnerskih sadnica hrasta lužnjaka (Quercus robur L.) iz sjemenske regije gornja Posavina i Pokuplje (1.2.3.). Šumarski list, 9-10: 451.-458.

- Drvodelić, D., M. Oršanić, Z. Zeman 2012: Uspjeh pošumljavanja jednogodišnjim $(1+0)$ i školovanim $(1+1)$ sadnicama divlje kruške (Pyrus pyraster Burgsd.). Šumarski List, 7-8: 355.-366.

- Drvodelić, D., M. Oršanić, S. Perić, M. Tijardović, 2013: Utjecaj navodnjavanja i mikroreljefa u rasadniku na morfološke značajke šumskih sadnica hrasta lužnjaka (Quercus robur L.) i kitnjaka (Quercus petraea L.). Šumarski list, 9-10: 447.-459.

- Drvodelić, D., M. Oršanić, V. Paulić, 2015: Utjecaj AgroHidroGela i ektomikorize na preživljenje i početni rast sadnica hrasta lužnjaka (Quercus robur L.). Proizvodnja hrane i šumarstvo temelj razvoja istočne Hrvatske / Matić, Slavko ; Tomić, Franjo ; Anić, Igor (ur.). - Zagreb: Hrvatska akademija znanosti i umjetnosti, 271.-294. str.

- Drvodelić, D., M. Oršanić, V. Paulić, 2016a: Utjecaj ektomikorize i huminskih kiselina na morfološke značajke jednogodišnjih sadnica hibrida Paulownia tomentosa $\times$ Paulownia fortunei. Šumarski list, 7-8: 327.-337.

- Drvodelić, D., D. Ugarković, M. Oršanić, V. Paulić, 2016b: The Impact of Drought, Normal Watering and Substrate Saturation on the Morphological and Physiological Condition of Container Seedlings of Narrow-Leaved Ash (Fraxinus angustifolia Vahl). South-east Eur for., 7 (2): 135.-142.

- Drvodelić, D., D. Ugarković, M. Oršanić, V. Paulić, 2016c: The Impact of Drought, Normal Watering and Substrate Saturation on the Morphological and Physiological Condition of Container Seedlings of Narrow-Leaved Ash (Fraxinus angustifolia Vahl). Seefor, 7 (2): 135.-142.

- Drvodelić, D., 2017: Ekologija i obnova poplavnih šuma Posavine, 2017: Znanstveno-istraživački projekt. Završno pisano trogodišnje izvješće pod projekta Uzgajanje šuma „Problematika sjemenarstva i rasadničke proizvodnje sadnica poljskog jasena (Fraxinus angustifolia Vahl.) i hrasta lužnjaka (Quercus robur L.)“, 
ur. Damir Drvodelić, Sveučilište u Zagrebu, Šumarski fakultet. U tisku. 75. str.

- Drvodelić, D., M. Oršanić, 2019: Izbor kvalitetne šumske sadnice poljskog jasena (Fraxinus angustifolia Vahl) za umjetnu obnovu i pošumljavanje. Šumarski list, 11-12: 577-585.

- Faulconer, J. R., 1988: Using frost hardiness as an indicator of seedling condition. In: Landis TD, technical coordinator. Proceedings, combined meeting of the western forest associations; 1988 August 9-11; Vernon, BC. Fort Collins (CO): USDA Forest Service, Rocky Mountain Forest and Range Experiment Station. General Technical Report RM-167: 89.-95. str.

- Glerum, C., 1984: Frost hardiness of coniferous seedlings: principles and applications. In: M. L. Duryea, editor. Evaluating seedling quality: principles, procedures, and predictive abilities of major tests. Proceedings of a workshop held October 16-18, 1984. Corvallis (OR): Oregon State University, Forest Research Laboratory: 107.-123. str.

- Haase, D. L., R. W. Rose, J. Trobaugh, 2006: Field performance of three stock sizes of Douglas-fir container seedlings grown with slow release fertilizer in the nursery growing medium. New Forests, 31: 1.-24.

- Haase, D. L., 2007: Morphological and Physiological Evaluations of Seedling Quality. USDA Forest Service Proceedings RMRSP-50: 3.-8. str.

- Harrington, J. T., J. D. Mexal, J. T. Fisher, 1994: Volume displacement method provides a quick and accurate way to quantify new root production. Tree Planters' Notes, 45: 121.-124.

- Harris, R. W., Clark, J. R., N. P. Matheny, 2004: Arboriculture, Integrated Management of Landscape Trees, Shrubs, and Vines. Upper Saddle River, New Jersey, USA. 578. str.

- ISO 10390, 1994: Soil quality - Determination of pH. ISO, Genève.

- ISO 10693, 1995: Soil quality - Determination of carbonate content - Volumetric method, ISO, Genève.

- ISO 10694, 1995: Soil quality - Determination of organic and total carbon after dry combustion (elementary analysis). ISO, Genève.

- ISO 11464, 1994: Soil quality - Pretreatment of samples for physico-chemical analyses. ISO, Genève.

- ISO 13878, 1998: Soil quality - Determination of total nitrogen content by dry combustion (elemental analysis). ISO, Genève

- Jelić, G., V. Topić, L. Butorac, Z. Đurđević, A. Jazbec, M. Oršanić, 2014: Utjecaj veličine kontejnera i pripreme tla na uspjeh pošumljavanja jednogodišnjim sadnicama bora pinije (Pinus pinea L.) na sredozemnom području Republike Hrvatske. Šumarski list, 9-10: 463-475.

- Jacobs, D. F., K. F. Salifu, J. R. Seifert, 2005: Relative contribution of initial root and shoot morphology in predicting field performance of hardwood seedlings. New Forests, 30: 235.-251.

- Komlenović, 1997: Utjecaj gnojiva "Osmocote Plus" na uspijevanje i kvalitetu sadnica poljskog jasena (Fraxinus angustifolia Vahl). Radovi: 32 (1): 67-75.

- Kozlowski, T. T., J. H. Torrie, P. E. Marshall, 1973: Predictability of shoot length from bud size in Pinus resinosa Ait. Canadian Journal of Forest Research, 3: 34.-38.

- Landis, T. L., 1985: Mineral nutrition as an index of seedling quality. In: M. L. Duryea, editor. Evaluating seedling quality: principles, procedures, and predictive abilities of major tests. Proceedings of a workshop held October 16-18, 1984. Corvallis (OR): Oregon State University, Forest Research Laboratory: 29.-48. str.

- Lavender, D. L., 1985: Bud dormancy. In: M. L. Duryea, editor. Evaluating seedling quality: principles, procedures, and predictive abilities of major tests. Proceedings of a workshop held Oc- tober 16-18, 1984. Corvallis (OR): Oregon State University, Forest Research Laboratory: 7.-15. str.

- Lopushinsky, W., 1990: Seedling moisture status. In: R. Rose, S. J. Campbell, T. D. Landis, editors. Target seedling symposium: combined proceedings of the western forest nursery associations; 1990 August 13-17; Roseburg, OR. Fort Collins (CO): USDA Forest Service, Rocky Mountain Forest and Range Experiment Station. General Technical Report RM-200: 123.-138. str.

- Mehlich, A., 1984: Mehlich-3 soil test extractant: a modification of Mehlich-2 extractant. Commun. Soil Sci. Plant Anal., 15 (12): 1409.-1416.

- Mexal, J. G., Landis, T. D. 1990: Target seedling concepts: height and diameter. In: Rose, R., S. J. Campbell, T. D. Landis, editors. Target seedling symposium: combined proceedings of the western forest nursery associations; 1990 August 13-17; Roseburg, OR. Fort Collins (CO): USDA Forest Service, Rocky Mountain Forest and Range Experiment Station. General Technical Report RM-200: 17.-35. str.

- Omi, S. K., G. T. Howe, M. L. Duryea, 1986: First-year field performance of Douglas-fir seedlings in relation to nursery characteristics. In: Landis TD, editor. Proceedings, combined Western Forest Nursery Council and Intermountain Nursery Association meeting; 1986 Aug 12-15; Tumwater, WA. Fort Collins (CO): USDA Forest Service, Rocky Mountain Forest and Range Experiment Station USDA. General Technical Report RM 137: 29.34. str.

- Oršanić, M., D. Drvodelić, I. Kovačević, 2007: Rasadnička proizvodnja sadnica crnog oraha (Juglans nigra L.). Šumarski list 131, ( 5-6): 207.-217.

- Oršanić, M., D. Horvat, N. Pernar, M. Šušnjar, D. Bakšić, D. Drvodelić, 2008: Growth of Pedunculate Oak Seedlings under Soil Contamination by Mineral and Biodegradable Oils. Croatian journal of forest engineering, 29 (2): 155.-162.

- Oršanić, M., D. Horvat, N. Pernar, M. Šušnjar, D. Bakšić, D. Drvodelić, 2008: Utjecaj mineralnog i biorazgradivog ulja na rasadničku klijavost i rast sadnica hrasta lužnjaka (Quercus robur L.). Šumarski list, 131 (1-2): 3.-9.

- Oršanić, M., D. Drvodelić, D. Bobinec Mikek, V. Paulić, 2010: Utjecaj potencijala rasta korijena na preživljavanje i rast sadnica crnog bora (Pinus nigra Arnold). Glasnik za šumske pokuse, 43: 61.-72.

- Owens, J. N., M. Molder, 1973: A study of DNA and mitotic activity in the vegetative apex of Douglas-fir during the annual growth cycle. Canadian Journal of Botany, 51: 1395.-1409.

- Paterson J. DeYoe D., S. Millson, R. Galloway, 2001: In: R. G. Wagner, S. J. Colombo, editors. Regenerating the Canadian forest principles and practice for Ontario. Markham (ON): Ontario Ministry of Natural Resources and Fitzhenry \& Whiteside Ltd: 325.-341.

- Ritchie, G. A. 1984. Assessing seedling quality. In: Duryea ML, Landis TD, editors. Forest nursery manual: production of bare root seedlings. Boston (MA): Martinus Nijhoff/Dr W Junk Publishers. 243.-259. str.

- Ritchie, G. A., 1985: Root growth potential: principles, procedures and predictive ability. In: M. L. Duryea, editor. Evaluating seedling quality: principles, procedures, and predictive abilities of major tests. Proceedings of a workshop held October 1618,1984. Corvallis (OR): Oregon State University, Forest Research Laboratory: 93.-106. str.

- Roller, K. J., 1977: Suggested minimum standards for containerized seedlings in Nova Scotia. Fisheries and Environment Canada, Canadian Forestry Service, Maritimes Forest Research Centre. Information Report M-X-69: 18. str. 
- Rose, R., D. L. Haase, F. Kroiher, T. Sabin, 1997: Root volume and growth of ponderosa pine and Douglas-fir seedlings: a summary of eight growing seasons. Western Journal of Applied Forestry, 12: 69.-73.

- Rose, R., J. S. Ketchum, 2003: Interaction of initial seedling diameter, fertilization, and weed control on Douglas-fir growth over the first four years after planting. Annals of Forest Science, 60: 625.-635.

- Simpson, D. G., 1990: Frost hardiness, root growth capacity, and field performance relationships in interior spruce, lodgepole pine, Douglas-fir, and western hemlock seedlings. Canadian Journal of Forest Research, 20: 566.-572.

- Simpson, D. G., G. A. Ritchie, 1997: Does RGP predict field performance? A debate. New Forests, 13: 253.-277.

- Smith, J. H., 1975: Big stock vs. small stock. In: Proceedings of the Western Forest Fire Committee; 1975 Dec 2-3; Vancouver, British Columbia. 107.-115. str.

- South, D. B., J. G. Mexal, J. P. van Buijtenen, 1988: The relationship between seedling diameter at planting and long term volume growth of loblolly pine seedlings in east Texas. IN: Proceedings of the 10th North American Forest Biology Workshop; 1988 July 20-22; Vancouver, British Columbia. 192.-199. str.
- Tanaka, Y., P. Brotherton, S. Hostetter, D. Chapman, S. Dyce, J. Belanger, B. Johnson, S. Duke, 1997: The operational planting stock quality testing program at Weyerhaeuser. New Forests, 13: 423.-437.

- Thompson, B. E., 1985: Seedling morphological evaluationwhat you can tell by looking. In: Duryea ML, editor. Evaluating seedling quality: principles, procedures, and predictive abilities of major tests. Proceedings of a workshop held October 16-18, 1984. Corvallis (OR): Oregon State University, Forest Research Laboratory: 59.-71. str.

- Tsakaldimi, M., T. Zagas, T. Tsitsoni, P. Ganatsas, 2005: Root morphology, stem growth and field performance of seedlings of two Mediterranean evergreen oaks species raised in different container types. Plant Soil 278: 85-93.

- van den Driessche, R., 1980: Effects of nitrogen and phosphorus fertilization on Douglas-fir nursery growth and survival after outplanting. Canadian Journal of Forest Research, 10: 65.-70.

- Vukadinović, V., V. Vukadinović, 2011: Ishrana bilja. Sveučilište Josipa Jurja Strossmayera u Osijeku. Poljoprivredni fakultet u Osijeku. 442 str.

- https://www.silvamix.com/

- http://www.bccab.com/

- https://everris.com

\section{Summary}

This review article lists and explains the benefits of planting activities undertaken in late summer and early fall, as well as spring planting before vegetation begins. Both irregular and correct digging of the plant pit and irregular and correct planting of bare-root seedlings of narrow-leaved ash are described and shown with the original illustrations. The influence of soil compaction on seed germination, seedling development, morphological characteristics of the above and below ground part of seedlings and root system is explained. The disadvantages of container production of forest seedlings in pure organic medium such as black peat and the disadvantages of planting seedlings produced in the field are discussed. Properly and incorrectly planted fields of narrow-leaved ash seedlings have been described and shown with the original illustrations. Modern technology of nursery production of narrow-leaved ash seedlings in containers and the benefits of afforestation of seedlings of coated root are presented. Container production is semi-automated and planting in the field should be done exclusively with the help of planters, whose features and advantages are presented in the article. Innovative solutions for the construction of a planter are described with regard to the shape of the hole that they make. It is important that the holes made by the planters are not round or square / rectangular, otherwise the planting holes will break or burst away from the surrounding soil. In the case of planters operating a rhombus-shaped hole or dug-in planting pit, there is no cracking at the edge of the hole, but the hole shoots all over the profile, which is more favorable to the root system of the plant. The original illustrations show examples of poor and good geometric shapes of a plant pit. An example taken from the Brestje nursery in Sesvete (Croatian Forests Ltd.) is used to illustrate the technology of nursery production of container seedlings of narrow-leaved ash. The data from the substrate declaration used in container production of seedlings were compared with the results of our own chemical analyzes at the time of planting the seedlings in the field after one growing vegetation. The extraction of elements from the substrate samples is described and so is the preparation of samples for trace element content determination by the ICP-AES technique. The values of the main substrate parameters obtained by the ICP-AES technique are presented, as well as the content of macro and micro nutrients in the substrate. The article presents the main morphological characteristics of container seedlings of narrow-leaved ash planted in the Lipovljani forest area in autumn 2017. In particular, the appearance of the washed root system of an average container seedling and its morphological analysis by means of WinRHIZO ProLA2400 (2005) scanner and software are presented. The causes of high mortality of narrow-leaved ash seedlings during afforestation in the Republic of Croatia are described, and concrete measures are proposed to improve the current situation in line with good forestry practices implemented in the countries of Central Europe and Scandinavia. 